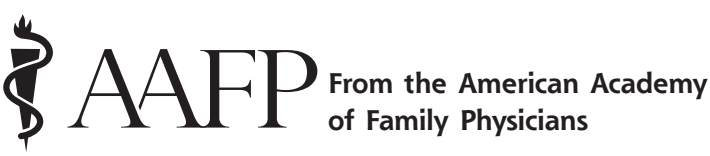

Ann Fam Med 2019;17:378-379. https://doi.org/10.1370/afm.2430.

\section{AAFP JOINS REBUILD RURAL INFRASTRUCTURE COALITION}

The AAFP has joined more than 240 organizations across the country to become a working partner in the Rebuild Rural Infrastructure Coalition. In an interview with AAFP News, Julie Wood, MD, MPH, AAFP senior vice president for health of the public, science, and interprofessional activities, said the Academy's participation in the coalition aligns perfectly with the organization's focus on rural health care.

"We're at the beginning stages of engagement with this group," said Wood. "The AAFP will help other members of the coalition understand issues around primary care in rural America-who we are, what we do, and our impact on patients and rural communities. We'll be the voice of expertise in this area," she added.

Wood noted the importance of the AAFP's involvement with organizations that represent other facets of life in rural America. Indeed, the groups' backgrounds are as varied as their locations-the Alaska Power Association, Alabama Farmers Federation, American Dairy Coalition, Cooperative Network, Idaho Grain Producers Association, Michigan Bean Shippers, National Black Growers Council, National Grange and Water Well Trust, to name just a handful.

Missing from the list of coalition partners-before the AAFP's decision to join - was the name of a single physician organization. "It's time for the AAFP to step outside its normal sphere and learn from other individuals who share our passion for the future well-being of families who call America's rural and sometimes remote towns home," said Wood. It should be noted that the National Rural Health Association is also a member of the coalition.

\section{Rebuild Rural Background}

Mark Hayes is vice president of external communications for the Farm Credit Council in Washington, DC. He also serves as the press contact for the Rebuild Rural Coalition. In an interview with AAFP News, Hayes explained that the collation was founded early in 2017 when the Trump administration was having conversations about an infrastructure package. His organization, along with several others, began talking about the host of past proposals that strongly favored urban areas. "We wanted to create a coalition that could raise the voice of rural communities to make sure that some of that funding, in a dedicated way, was set aside for rural communities and their infrastructure," said Hayes. He ticked off the 8 specific topic areas the coalition embraces:

- agricultural research

- health care

- broadband Internet

- housing

- energy

- transportation

- financing

- water

"It's everything that makes rural communities viable and that will encourage the next generation to want to live there," said Hayes. He noted that local, state, and national groups have come together to make sure the Trump administration and Congress understand that rural communities have unique needs. Hayes also pointed out that America's rural population is declining - and that means fewer members of Congress who represent rural areas. "We felt it was really important to make sure lawmakers and policymakers understand the need out there, and the best way to do that is to create a critical mass-and so, with more than 240 organizations, we have a lot of the country covered," he said.

And just how can the AAFP help in this effort? "A huge advantage the AAFP has is that its members represent the boots on the ground. As physicians, they know the health care situation intimately; they know that 102 hospitals have closed since 2010 and that 700 more are vulnerable to closure," said Hayes. Physicians also know that when people have to drive 30 , 60 , or 100 miles to get to a doctor, "that poses a lot of challenges." Family physicians working in these communities understand the economic benefit that health care facilities bring-not only in well-paying jobs, but in sustainability for the entire area, said Hayes. "We're excited to have AAFP members bring their voices to this debate as we educate and influence lawmakers about the importance of setting aside funding for rural communities-particularly when it comes to health care," said Hayes.

\section{Letter to Congress}

Early in 2019, before the AAFP joined its ranks, Rebuild Rural called on the leaders of the 116th Congress for assistance. In a Feb. 5 letter to Senate Majority Leader Mitch McConnell, R-Kentucky; Senate Minority Leader Charles Schumer, D-New York; Speaker of the House Nancy Pelosi, D-California; and House Minority Leader Kevin McCarthy, R-California, the coalition came quickly to the point. "As you set the strategic goals for the new Congress, the Rebuild Rural Coalition strongly 
encourages you to move quickly to pass bipartisan legislation to strengthen our nation's infrastructure, including specific provisions focused on the unique needs of rural communities and agriculture," the letter urged. "We live and work every day in rural America and deeply understand the realities these communities face in order to remain prosperous and vibrant. We also understand that rural communities' needs are unique, oftentimes differing greatly from the realities of our urban counterparts," the letter continued.

The coalition pointed out the important role that rural communities play in the American economyproviding "food and fiber for our country and the world, creating jobs for millions of Americans." The coalition called on the federal government to continue to not only provide-but to increase-infrastructure funding in rural communities.

Lastly, the letter pledged the coalition's support in looking for creative solutions that include federal, state, and local investments, as well as private sources of capital. "We stand ready to work with you ... to help identify and implement these vital rural infrastructure improvements," said coalition members.

Sheri Porter

AAFP News Department

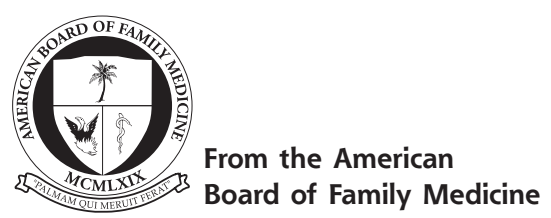

Ann Fam Med 2019;17:379-381. https://doi.org/10.1370/afm.2435.

\section{IMPROVING QUALITY IMPROVEMENT}

In February 2019, the Vision Committee recommended that the American Board of Medical Specialities

(ABMS) chart a new course for improvement in medical practice. ${ }^{1}$ Arguing that the Maintenance of Certification (MOC) requirement for improvement in medical practice had become onerous for some Diplomates and challenging to implement for many specialties, the Vision Committee called for the identification of new approaches to advancing practice while recognizing what Diplomates are already doing.

How did we start on the quality journey? Though systematic efforts to improve care date back at least as far as Semmelweis and Florence Nightingale, the 1999 and 2001 IOM reports "To Err is Human"2 and the "Crossing the Quality Chasm"3 transformed professional and legislative discourse about patient safety and the quality of care in the United States. The authors argued powerfully that error was common in health care, that it had important consequences for patients and that it was not primarily due to clinicians' mistakes but rather the lack of a culture of improvement and systems to prevent error and improve care. Closely following was empiric evidence of a dramatic gap between what all agreed should happen clinically and what actually happened in practice across the entire continuum of care. ${ }^{4}$ Thus, as ABMS developed the Maintenance of Certification program, a cornerstone was support of improvement of quality of care. ${ }^{5}$

What progress have we made in quality improvement in the 20 years since the publication of the original Institutes of Medicine report? An entire industry has developed around supporting this work: quality improvement goals and activities have been institutionalized in medical practices and hospital systems across the country. Reflecting this broad commitment, there are countless examples of improvement in measures of care across clinical settings ranging from primary care to inpatient care and long-term care. At the same time, however, the payers, agencies and others driving this process have worked largely independently from each other, resulting in an explosion of metrics, often with small differences that prevent comparisons across providers or geographies. Few measures have taken into account variations in patient populations and social determinants of health. Consequently, despite progress, major problems in care remain, and many promising quality improvement projects have failed to spread or be sustained. ${ }^{6}$ Moreover, the intrinsic motivation of physicians to improve the quality of care they provide has been challenged by administrative burden and often seemingly arbitrary metrics that vary by individual payers and organizations. Backlash is substantial, with both physicians and specialty organizations complaining about "meaningless" quality improvement activities.

So how will the American Board of Family Medicine proceed? Since its founding, ABFM has believed that assessment of cognitive expertise through periodic examination is insufficient for recertification. All Diplomates were required to recertify - an innovation across the Board Community - and all had to demonstrate excellence in practice, as measured by a practice audit, as well as continuing education and evidence of ethical professional conduct, in addition to an examination. ${ }^{7}$

In recent years, we have made increased performance improvement (PI) offerings available to Diplomates, aimed at increasing relevance by providing more options across a wide spectrum of practice types and scope. In particular, our Self-Directed pathway allows physicians who are already meaningfully participating in quality improvement $(\mathrm{QI})$ efforts in their 